\title{
PENGGUNAAN CHITOSAN DAN SODIUM TRI POLIPHOSPAT PADA JAJANAN BAKSO
}

\author{
${ }^{1}$ Uun Kunaepah, ${ }^{2}$ Anis Abdul Muis, ${ }^{3}$ Ayu Yuliani S. \\ 1, 2, 3. Dosen Poltekkes Kemenkes Tasikmalaya.
}

\begin{abstract}
Abstrak
Bahan Tambahan Pangan (BTP) adalah bahan yang ditambahkan ke dalam pangan untuk mempengaruhi sifat atau bentuk pangan. Penelitian ini bertujuan untuk mengetahui gambaran penggunaan BTP chitosan dan STTP dalam pemanfaatan bahan pangan lokal Ikan Tunul pada pembuatan bakso sebagai alternatif makanan jajanan anak sekolah. Desain penelitian adalah eksperimental yang dilakukan secara bertahap mulai dari persiapan bahan, formulasi, pelaksanaan, pengujian mutu organoleptik, kekenyalan dan nilai gizi bakso ikan tunul. Penilaian suka terhadap rasa bakso ikan tunul sebanyak 38,3\% dengan penambahan Chitosan dan $33,3 \%$ dengan penambahan STPP. Penilaian suka terhadap warna bakso ikan tunul sebanyak $45 \%$ dengan penambahan Chitosan dan $53,3 \%$ dengan penambahan STPP. Penilaian suka terhadap aroma bakso ikan tunul sebanyak 15\% dengan penambahan Chitosan dan 25\% dengan penambahan STPP. Penilaian suka terhadap tekstur bakso ikan tunul sebanyak $43,3 \%$ dengan penambahan Chitosan dan $45 \%$ dengan penambahan STPP. Penilaian suka terhadap penampilan bakso ikan tunul sebanyak $46,7 \%$ dengan penambahan Chitosan dan 30\% dengan penambahan STPP. Hasil uji menggambarkan bahwa anak-anak dapat menerima bakso yang terbuat dari ikan tunul yang sangat bermanfaat bagi pertumbuhan. Bakso ikan tunul dapat ditambahkan pada beberapa macam makanan jajanan lainnya.
\end{abstract}

Kata kunci: Bakso, Ikan Tunul, Chitosan, STPP

\begin{abstract}
Food Additives (BTP) are ingredients added to food to affect the nature or form of food. This study aims to describe the use BTP of chitosan and STTP in the utilization of local food of tunul fish on making meatballs as an alternative snack foods schoolchildren. Experimental research design is done in stages from preparation ingredients, formulation, implementation, testing organoleptic quality, suppleness and nutritional value of fish balls tunul. Ratings like the taste of fish balls tunul as much as $38.3 \%$ with the addition of Chitosan and $33.3 \%$ with the addition of STPP. Rate likes to color tunul fish balls as much as $45 \%$ with the addition of Chitosan and $53.3 \%$ with the addition of STPP. Ratings like the scent of balls tunul fish as much as $15 \%$ with the addition of Chitosan and $25 \%$ with the addition of STPP. Ratings like the texture of the balls tunul fish as much as $43.3 \%$ with the addition of Chitosan and $45 \%$ with the addition of STPP. Ratings like the appearance of balls tunul fish as much as $46.7 \%$ with the addition of Chitosan and $30 \%$ with the addition of STPP. The test results illustrate that children can receive meatballs made from tunul fish that are beneficial to growth. The balls tunul fish can be added to some other kinds of street food.
\end{abstract}

Keywords: Meatballs, tunul fish, chitosan, STPP.

\section{PENDAHULUAN}

Bahan Tambahan Pangan (BTP) adalah bahan yang ditambahkan ke dalam pangan untuk mempengaruhi sifat atau bentuk pangan. BTP adalah nama kimia/generik yang lazim digunakan untuk identitas bahan tambahan pangan, dalam bahasa Indonesia atau dalam bahasa Inggris. Preservative adalah bahan tambahan pangan untuk mencegah atau menghambat fermentasi, pengasaman, penguraian, dan perusakan lainnya terhadap pangan yang disebabkan oleh mikroorganisme (Cahyo dkk, 2006).

Bakso salah satu produk olahan yang sangat popular dan digemari masyarakat. Bakso banyak ditemukan di pasar tradisional dan supermarket. Bakso dibuat dari daging giling dengan bahan tambahan utama tepung tapioka, garam dapur dan bumbu-bumbu dicampur menjadi adonan dan dibentuk bulat seperti kelereng dengan berat 25-30 gram per butir (Widyaningsih dkk, 2006). 
Ikan Tunul merupakan ikan laut yang banyak dihasilkan di Cirebon sebagai bahan pangan local. Ikan tunul dapat dikembangkan untuk dibuat berbagai macam olahan salah satunya adalah dibuat bakso. Bakso yang dibuat dengan bahan dasar ikan Tunul untuk makanan jajanan masih jarang dilakukan.

Ikan Tunul memiliki kandungan nilai gizi protein yang cukup tinggi. Pemanfaatan protein dapat memenuhi kebutuhan protein di masyarakat terutama pada anak sekolah. Produk olahan bakso umumnya mempunyai masa simpan yang relatif singkat, salah satu usaha untuk memperpanjang masa simpan bakso adalah dengan memanfaatkan bahan tambahan pangan (pengawet).

Chitosan dapat digunakan sebagai pengawet karena sifat-sifat yang dimiliki yaitu dapat menghambat pertumbuhan mikroorganisme (Wijayanti, 2010). STPP merupakan bahan tambahan pangan dengan tipe fosfat yang umum digunakan dalam produk daging karena cukup aktif dan harganya relatif murah. Penggunaan polyphospat memiliki pembatas karena polyphospat memiliki rasa yang agak pahit pada konsentrasi tertentu sehingga penggunaannnya pada umumnya sekitar 0.3-0.5\% (Ranken 1976).

Penelitian ini bertujuan untuk mengetahui gambaran penggunaan BTP chitosan dan STTP dalam pemanfaatan bahan pangan lokal ikan tunul pada pembuatan bakso sebagai alternatif jajanan anak sekolah.

\section{METODE PENELITIAN}

Desain penelitian adalah eksperimental yang dilakukan secara bertahap mulai dari persiapan bahan, formulasi, pelaksanaan penelitian, pengujian mutu organoleptik, kekenyalan dan nilai gizi bakso ikan tunul.

Uji organoleptik yang diamati meliputi warna, rasa, aroma, tekstur dan penampilan bakso ikan tunul. Uji organoleptik merupakan salah satu metode uji yang digunakan untuk mengukur sikap subjektif konsumen terhadap produk berdasarkan sifat-sifat organoleptik atau suatu uji untuk mengetahui tingkat kesukaan panelis terhadap produk yang diuji. Panelis diminta memberikan penilaian sifat organoleptik pada produk makanan berdasarkan tingkat kesukaan panelis (Utami,2010 dalam Ratnawati,2011).

Penilaian organoleptik terhadap bakso ikan tunul dilakukan sebanyak 2 (dua) kali dengan rentang waktu 1 (satu) minggu. Panelis diminta memberikan penilaian terhadap 3 macam bakso yang digunakan dalam penelitian ini meliputi warna, rasa, aroma, tekstur dan penampilan pada kuesioner yang telah disediakan. Pada saat pengujian dilakukan dengan jarak antar panelis dan dilakukan secara bersamaan dengan didampingi oleh peneliti.

Penelitian dilakukan di laboratorium Teknologi Pangan Prodi D III Gizi Cirebon Poltekkes Tasikmalaya, sedangkan untuk analisis nilai gizi dilakukan pada CV. Chemix Pratama Yogyakarta. Penelitian dilaksanakan pada bulan Juli - Nopember 2015.

Hasil uji organoleptik terbaik dilanjutkan dengan uji organoleptik pada anak Madrasah Ibtidaiyah Islamiyah Sidamulya Kecamatan Astanajapura, Kabupaten Cirebon yang merupakan salah satu daerah pengabdian kepada masyarakat. Rancangan percobaan yang dilakukan adalah sebagai berikut :

Tabel 1. Tabel Rancangan Percobaan

\begin{tabular}{lcc}
\hline \multirow{2}{*}{ Perlakuan } & \multicolumn{2}{c}{ Pengulangan } \\
\cline { 2 - 3 } & $\mathrm{I}$ & $\mathrm{I}$ \\
\hline Tanpa Penambahan BTP & K1 & K2 \\
\hline Penambahan BTP Chitosan & PC1 & PC2 \\
\hline Penambahan BTP STPP & PS1 & PS2 \\
\hline
\end{tabular}

Penelitian dilakukan secara bertahap mulai dari dari persiapan bahan, formulasi, perlakuan, pengamatan, uji organoleptik dan uji daya terima. Rancangan percobaan yang dilakukan adalah sebagai berikut :

Keterangan :

$\mathrm{K}=$ Tanpa penambahan BTP

$\mathrm{PC}=$ Penambahan BTP Chitosan

PS = Penambahan BTP STPP

Tabel 2. Tabel Rancangan Percobaan

\begin{tabular}{lcc}
\hline \multirow{2}{*}{ Perlakuan } & \multicolumn{2}{c}{ Pengulangan } \\
\cline { 2 - 3 } & $\mathrm{I}$ & $\mathrm{I}$ \\
\hline Tanpa Penambahan BTP & K1 & K2 \\
\hline Penambahan BTP Chitosan $2 \%$ & PC1 & PC2 \\
\hline Penambahan BTP STPP $2 \%$ & PS1 & PS2 \\
\hline
\end{tabular}


HASIL PENELITIAN

Tabel 3. Hasil dari pembuatan bakso dengan 3 perlakuan

\begin{tabular}{|c|c|c|c|}
\hline Perlakuan & Bahan Pembuatan & $\begin{array}{l}\text { Ulangan } 1 \\
\text { (Hasil dlm gr) }\end{array}$ & $\begin{array}{c}\text { Ulangan } 2 \\
\text { (Hasil dlm gr) }\end{array}$ \\
\hline Penambahan Chitosan 2\% & \multirow{3}{*}{$\begin{array}{l}\text { Ikan tunul } 250 \mathrm{gr} \\
\text { Merica } 1 \%(2,5 \mathrm{gr}) \\
\text { Garam } 2 \%(5 \mathrm{gr}) \\
\text { Bawang putih } 2 \%(5 \mathrm{gr}) \\
\text { Tapioka } 25 \%(62,5 \mathrm{gr}) \\
\text { Es batu } 40 \%(100 \mathrm{gr})\end{array}$} & 402 gram & 398 gram \\
\hline Tanpa Penambahan BTM & & 462 gram & 459 gram \\
\hline Penambahan STPP 2\% & & 456 gram & 451 gram \\
\hline
\end{tabular}

Hasil uji organoleptik yang dilakukan adalah sebagai berikut :

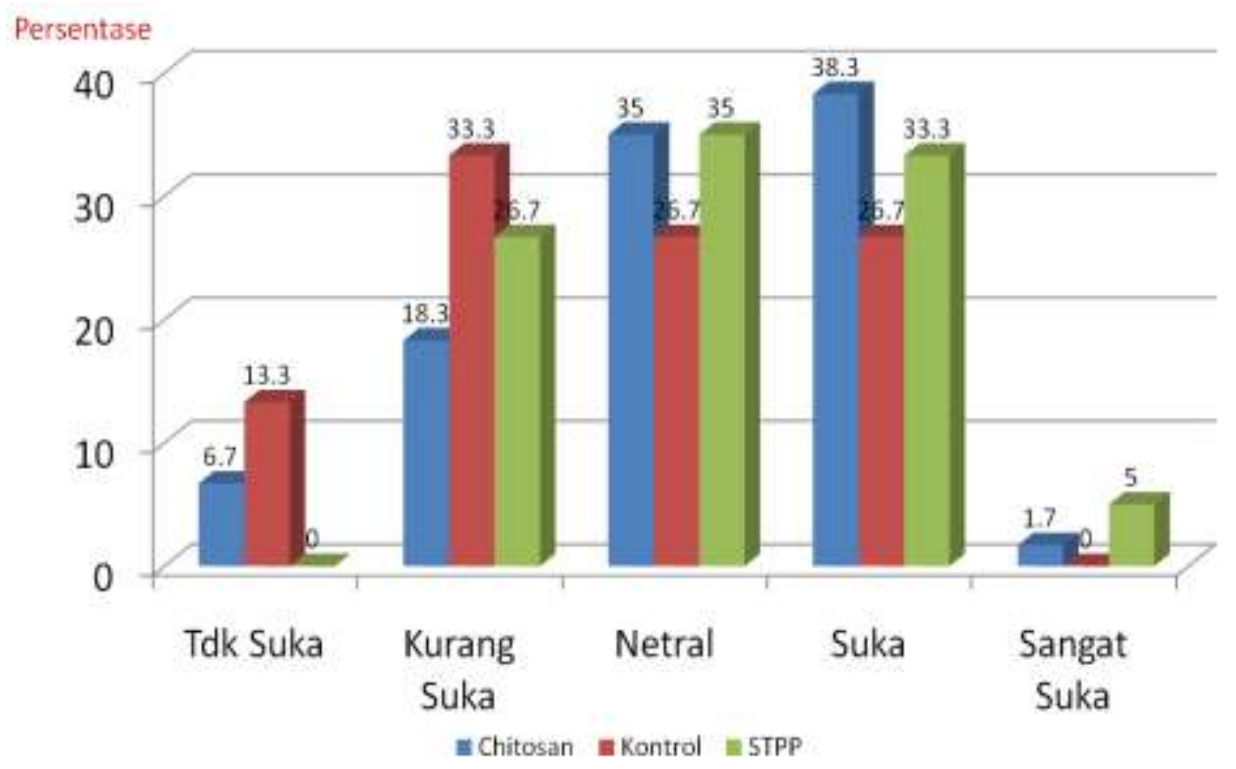

Grafik 1. Penilaian terhadap Rasa

Berdasarkan grafik 1, penilaian suka terhadap rasa bakso ikan tunul berdasarkan uji organoleptik adalah sebanyak 38,3\% dengan penambahan Chitosan dan 33,3\% dengan penambahan STPP. 


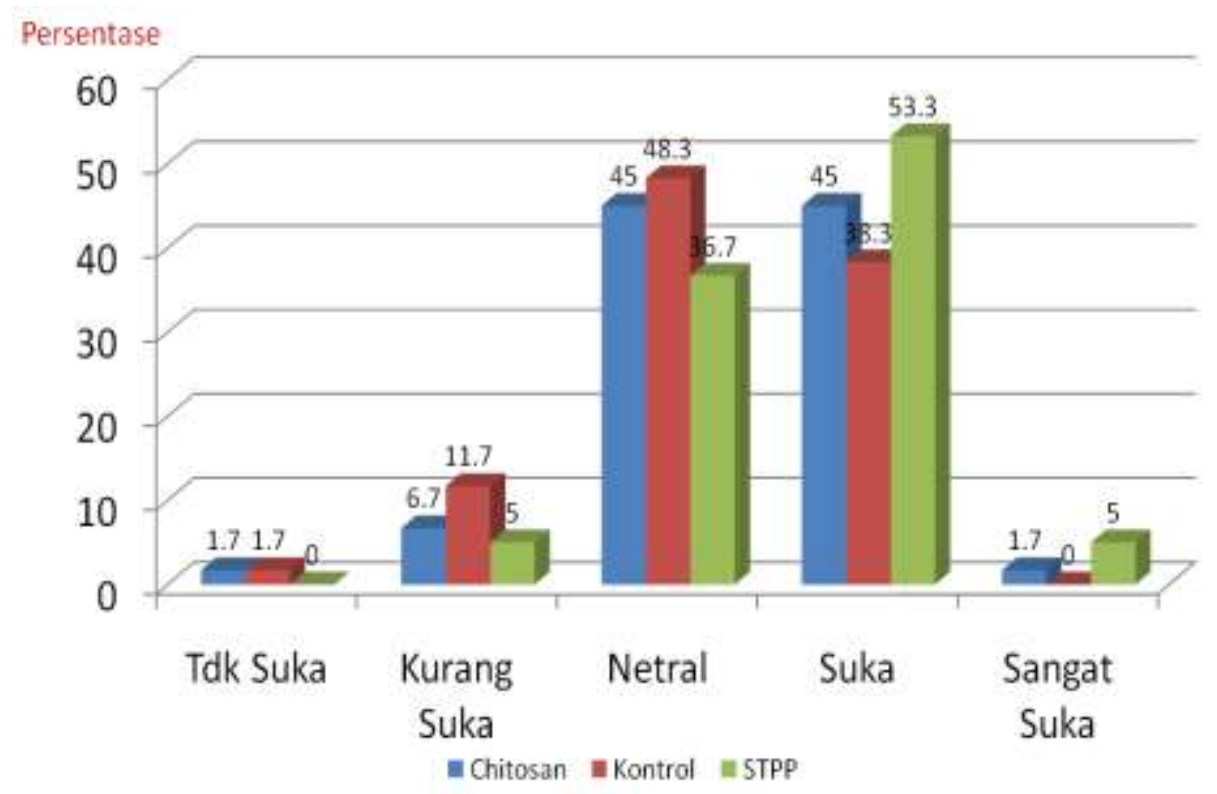

Grafik 2. Penilaian terhadap Warna

Berdasarkan grafik 2, penilaian suka terhadap warna bakso ikan tunul berdasarkan uji organoleptik adalah sebanyak $45 \%$ dengan penambahan Chitosan dan 53,3\% dengan penambahan STPP.

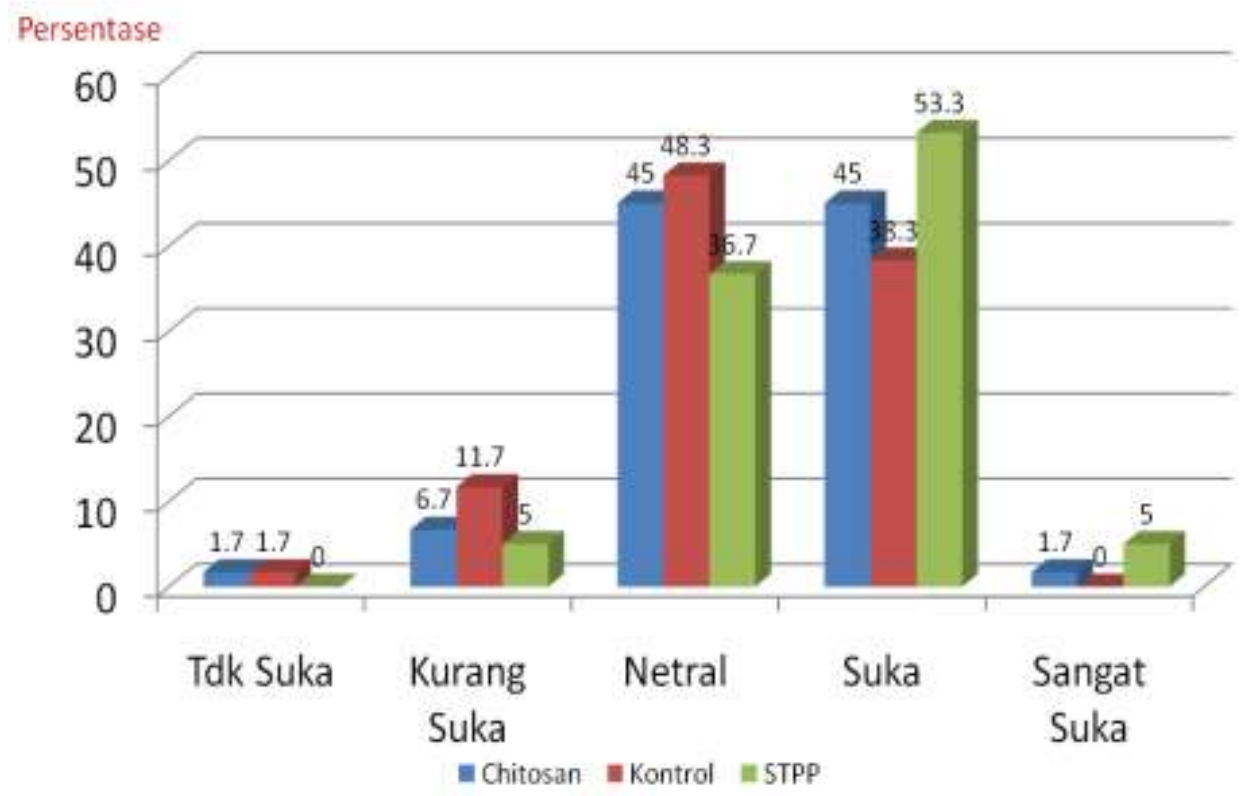

Grafik 3 Penilaian terhadap Aroma

Berdasarkan grafik 3, penilaian suka terhadap aroma bakso ikan tunul berdasarkan uji organoleptik adalah sebanyak $15 \%$ dengan penambahan Chitosan dan $25 \%$ dengan penambahan STPP. Aroma bakso ikan dipengaruhi juga oleh bahan tambahan yang ditambahkan yaitu Chitosan dan STPP. 


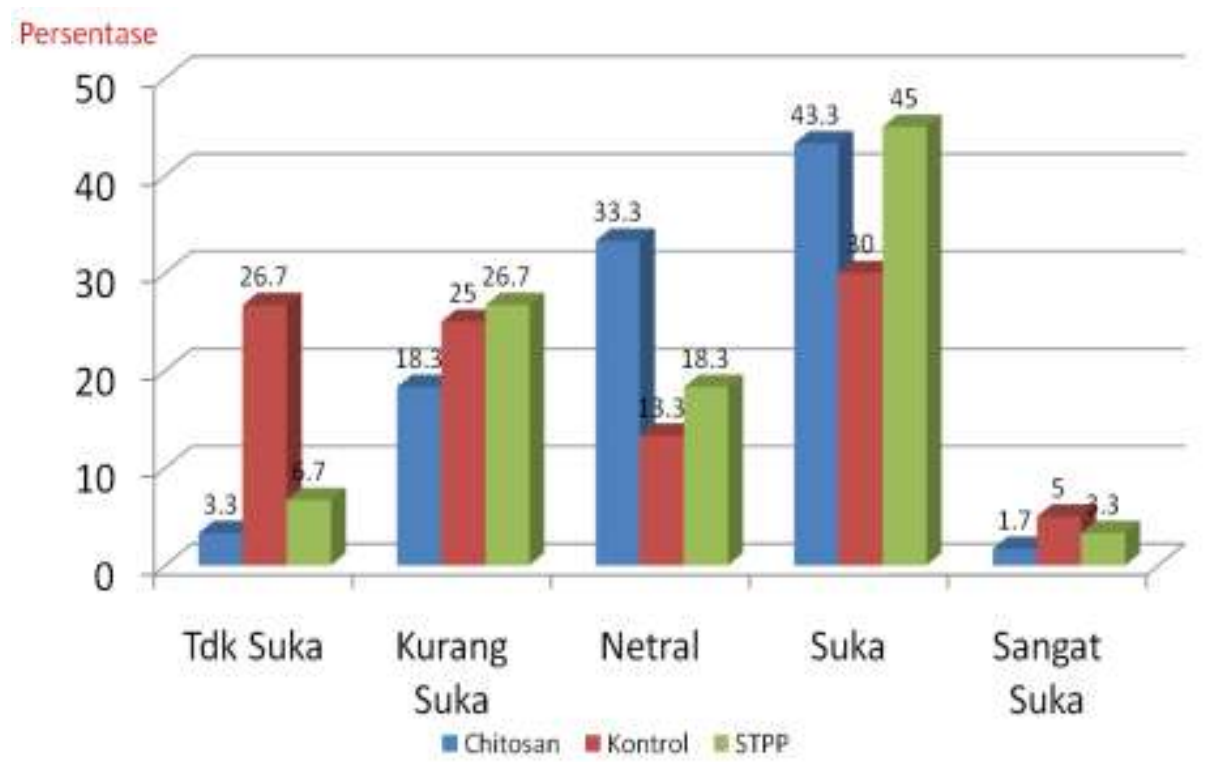

Grafik 4. Penilaian terhadap Tekstur

Berdasarkan grafik 4, penilaian suka terhadap tekstur bakso ikan tunul berdasarkan uji organoleptik adalah sebanyak $43,3 \%$ dengan penambahan Chitosan dan $45 \%$ dengan penambahan STPP.

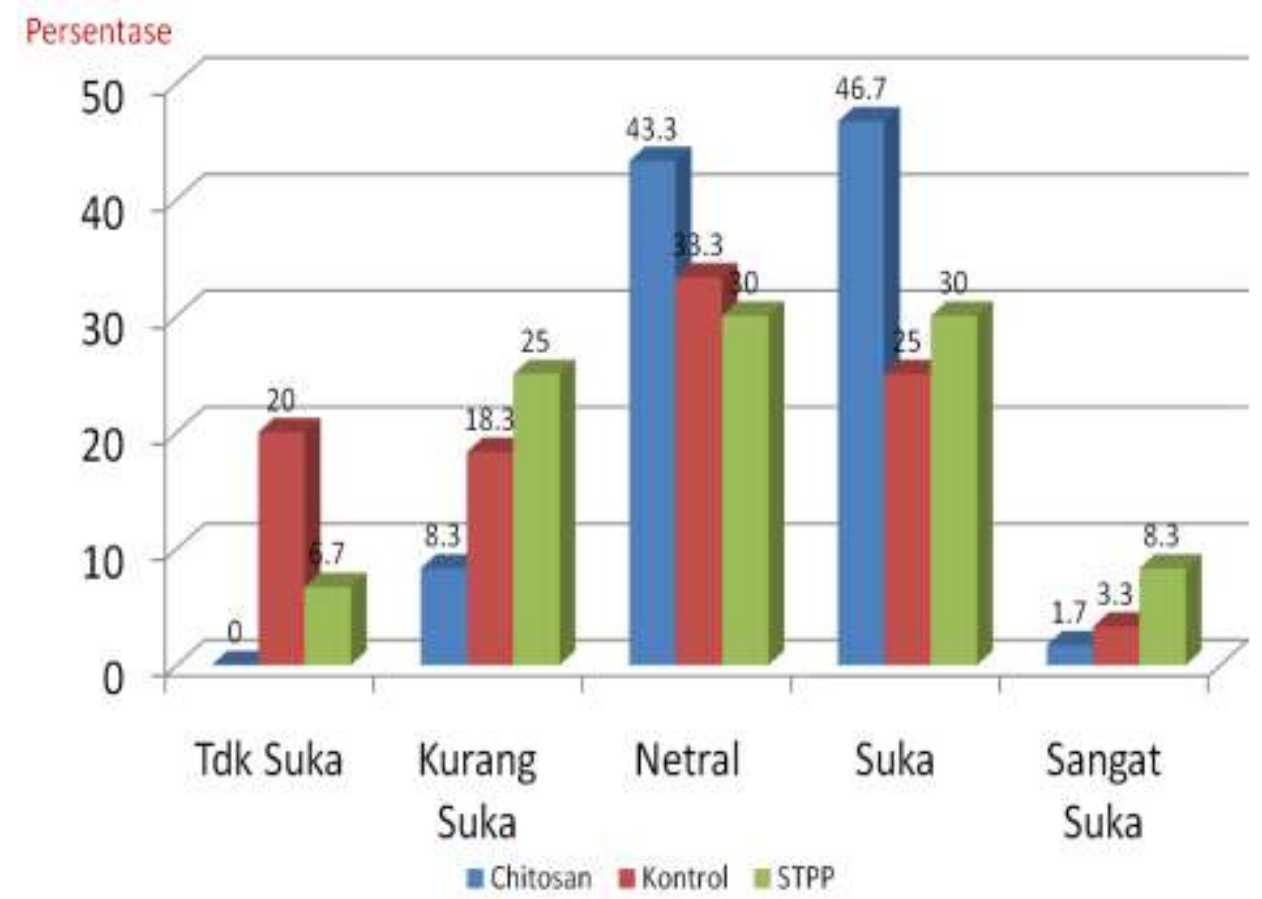

Grafik 5. Penilaian terhadap Penampilan

Berdasarkan grafik 5, penilaian suka terhadap penampilan bakso ikan tunul berdasarkan uji organoleptik adalah sebanyak 46,7\% dengan penambahan Chitosan dan 30\% dengan penambahan STPP. 


\section{PEMBAHASAN}

Grafik 1., penilaian suka terhadap rasa bakso ikan tunul berdasarkan uji organoleptic. Rasa bakso ikan dipengaruhi juga oleh bumbu yang ditambahkan meliputi bawang putih dan merica. Penambahan Chitosan juga memberikan rasa terhadap bakso ikan tunul karena Chitosan yang ringan membuat volume Chitosan yang ditambahkan menjadi besar sehingga mempengaruhi rasa bakso ikan tunul yang dihasilkan.

Grafik 2., penilaian suka terhadap warna bakso ikan tunul berdasarkan uji organoleptic. Warna bakso ikan dipengaruhi juga oleh bahan tambahan yang ditambahkan yaitu Chitosan dan STPP. Penambahan Chitosan dan STPP berpengaruh terhadap warna bakso ikan tunul menjadi terlihat lebih cerah/putih dan menarik. STPP yang berwarna lebih putih dibandingkan Chitosan membuat warna bakso ikan tunul dengan penambahan STPP lebih disukai daripada Chitosan.

Grafik 3, penilaian suka terhadap aroma bakso ikan tunul berdasarkan uji organoleptik. Penambahan Chitosan dan STPP berpengaruh terhadap aroma bakso ikan tunul disukai karena tidak terlalu tercium bau amis seperti bahan dasar pembuatannya.Panelis lebih banyak yang menyukai aroma bakso ikan tunul dengan penambahan STPP daripada dengan penambahan Chitosan. Chitosan adalah substansi alami dalam dinding sel, diproduksi dari kulit crustacean jenis udang-udangan seperti kepiting dan lobster. Selain itu juga terdapat pada kerangka luar exoskeleton seperti plankton, coral dan ubur-ubur, sehingga menyebabkan aroma yang kurang disukai.

Grafik 4., penilaian suka terhadap tekstur bakso ikan tunul berdasarkan uji organoleptic. STPP memiliki fungsi untuk meningkatkan $\mathrm{pH}$ daging, kestabilan emulsi dan kemampuan emulsi. Jika nilai $\mathrm{pH}$ semakin mendekati titik isoelektrik protein, maka daya mengikat air akan semakin rendah. Penambahan STPP dapat meningkatkan $\mathrm{pH}$ sehingga diperoleh daya mengikat air yang semakin tinggi serta dapat mencegah terjadinya rekahan bakso, sehingga menyebabkan tekstur bakso ikan tunul dengan penambahan STPP lebih disukai.

Grafik 5., penilaian suka terhadap penampilan bakso ikan tunul berdasarkan uji organoleptic. Chitosan memiliki sifat biodegradable dan biokompetibel, tidak mengandung racun dan banyak digunakan dalam industri. Chitosan dan turunannya merupakan antimikroba alami. Dengan adanya sifat tersebut, bakso ikan tunul dengan penambahan Chitosan menjadi disukai.

Hasil uji organoleptik yang terbaik diuji organoleptik pada anak-anak usia sekolah. Anak usia sekolah dasar digunakan sebagai uji coba karena merupakan salah satu kelompok umur yang menyukai makanan jajanan, terutama bakso. Kelompok anak sekolah dasar berada dalam masa pertumbuhan yang sangat membutuhkan protein. Salah satu protein yang dianjurkan berasal dari ikan laut. Pada uji daya terima, diberikan makanan jajanan/sncak berupa macaroni schotel. Macaroni schotel dipilih karena padat gizi, mengandung karbohidrat, lemak, protein dari ikan tunul serta vitamin dan mineral dari sayuran buncis dan wortel yang ditambahkan. Berdasarkan hasil uji menggambarkan bahwa anak-anak dapat menerima bakso yang terbuat dari ikan tunul yang sangat bermanfaat bagi pertumbuhan.

Menurut Estuti, W, dkk, 2006 penelitian tentang penggunaan STPP pada pembuatan bakso berbahan dasar daging ayam menunjukkkan bahwa untuk mendapatkan cita rasa bakso terbaik penambahan STPP sebanyak 1 gram per $\mathrm{kg}$ bahan. Dalam penelitian inipun dilakukan kajian lanjut tentang penggunaan BTP lain selain STPP.

Menurut Peraturan Menteri Kesehatan No. 722 tahun 1988 dan No.116 tahun 1999, bahan tambahan pangan adalah bahan yang biasanya tidak digunakan sebagai makanan dan bukan merupakan komponen khas makanan, dapat atau tidak mempunyai nilai gizi, yang dengan sengaja ditambahkan ke dalam makanan untuk maksud meningkatkan citarasa, mutu, daya simpan pada pembuatan, pengolahan, penyimpanan, 
perlakuan, pengepakan, dan pengemasan. Proses pengawetan produk dilakukan untuk menghindari dan mengurangi kemungkinan pencemaran suatu produk oleh mikroorganisme. Syarat zat pengawet mampu membunuh kontaminan mikroorganisme, tidak menyebabkan toksik atau iritasi pada pengguna, stabil dan aktif, serta selektif dan tidak berinteraksi dengan bahan.

\section{KESIMPULAN}

Pembuatan Bakso Ikan Tunul menggunakan 3 perlakuan penambahan BTM yang berbeda dengan komposisi bahan dasar yang sama. Hasil uji organoleptik yang paling banyak disukai oleh panelis adalah bakso ikan tunul dengan penambahan STPP. Uji Daya Terima didapatkan bahwa daya terima pada anak Madrasah Ibtidaiyah adalah sejumlah $93,75 \%$ menghabiskan bakso ikan tunul dan hanya $6,25 \%$ yang masih menyisakan $25 \%$ bakso ikan tunul. Analisis nilai gizi yang dilakukan adalah analisis kandungan energi, karbohidrat, protein, lemak, kadar air, kadar abu dan Fe.

\section{SARAN}

Perlu dilakukan uji daya terima pada kelompok sekolah lainnya seperti anak SMP dan SMA. Bakso ikan tunul dapat ditambahkan pada beberapa macam makanan jajanan lainnya.

\section{Referensi}

Afrianti, L.H., (2013). Pengawet Makanan Alami dan Sintetis. Bandung: .Alfabeta.

Andarwulan, Nu. dkk., (2011). Analisis Pangan. Jakarta: Dian Rakyat.

Buckle, K.A., R.A. Edward, G.H. Fleet and M. Wooton, (1985). Ilmu Pangan (diterjemahkan oleh Purnomo, $\mathrm{H}$ dan Adiono). Jakarta: UI Press.
Estuti, W., (2006). Pengaruh Penambahan Sodium Tripoliphosfat (STPP) sebagai Pengganti Bahan Tambahan (Boraks) Terhadap Sifat Fisik, Citarasa dan Daya Simpan Bakso Ayam. Laporan Penelitian Riset Binaan Tenaga Kesehatan.

Herliani, L., (2008). Teknologi Pengawetan Pangan. Bandung: Alfabeta.

Notoatmodjo, S., (2005). Metodologi Penelitian Kesehatan, edisi revisi. Jakarta: Asdi Mahasatya.

Rahayu W.P., (1998). Penuntun Praktikum Penilaian Organoleptik. Jurusan Teknologi Pangan dan Gizi, FATETA, IPB, Bogor.

Ranken M.D., (1976). Water Holding Capasityof meat and Its Control. Chem And Ind.24.

Ratnawati, (2011). Pengaruh Variasi penambahan Lidah Buaya (Aloevera) dalam Pembuatan Agar-agar Ditinjau dari Sifat Fisik, Organoleptik dan kadar beta karoten. Karya Tulis IImiah. Politeknik Kesehatan kemenkes Yogyakarta.

Sapanto, dkk., (2006). Bahan Tambahan Pangan. Yogyakarta: Kanisius.

Soekarto, S.T, (1985). Penilaian Organoleptik untuk Industri Pangan dan Hasil Pertanian. Bharata Jakarta : Karya Aksara.

Sudarmadji, S., (1989). Analisa Bahan Makanan dan Pertanian. Pusat Antar Universitas Pangan dan Gizi Universiotas Gadjah. Yogyakarta: Mada. Liberty.

Suprapti, I (2003). Teknologi Tepat Guna Membuat Bakso Daging dan Bakso lkan. Yogyakarta: Kanisius.

Winarno, (2002). Kimia Pangan dan Gizi, Gramedia. 